\title{
UNIQUE INNOVATION AND ECONOMIC SHOCK
}

Zsolt Selmeczi-Kovács - Dániel Kuttor-Gábor Németh - Zsolt Pál ${ }^{1}$

\begin{abstract}
The changes in March 2020 and in the following period have undoubtedly had a major impact on the Hungarian economy. At the beginning of the month we reached a milestone in payments in this country as instant payment services were launched on 2 March. It coincided - almost to the day - with the appearance of the COVID-19 pandemic in Hungary (the first registered case was published on 4 March).

Market players expected the implementation of the Instant Payment System to cause an increase in the number of transfers, a reduction in cash use and a boost to the economy, while the restrictive measures introduced in response to the virus situation might have exerted an adverse effect on most areas of business life.

In this study the authors investigate how those opposite effects were reflected in the figures of the Interbank Clearing System in the period from the beginning of March to the end of June 2020.
\end{abstract}

JEL codes: $\mathrm{E}_{42}, \mathrm{~N}_{24}, \mathrm{O}_{3} \mathrm{O}$

Keywords: clearing volumes, interbank clearing, clearinghouse, instant payment, digitisation, innovation, fintech, COVID-19, coronavirus, pandemic

\section{THE CLEARING AND SETTLEMENT INFRASTRUCTURE IN HUNGARY}

In Hungary there are three main clearing/settlement systems in operation:

I. The Real Time Gross Settlement System (VIBER) is operated by the National Bank of Hungary. It serves clearing and settlement of high-amount time critical payments.

1 Zsolt Selmeczi-Kovács, CEO of GIRO Zrt. E-mail: selmeczikovacs.zsolt@mail.giro.hu.

Dániel Kuttor, reader at the Institute of World and Regional Economics of Miskolc University.

E-mail: kuttor.daniel@uni-miskolc.hu.

Gábor Németh, head of department at GIRO Zrt. E-mail: nemeth.gabor@mail.giro.hu.

Zsolt Pál, reader at the Institute of Finance and Accounting of Miskolc University. E-mail: pal. zsolt@uni-miskolc.hu. 
II. The systems operated by KELER and KELER KSZF are responsible for spot and futures transactions in the securities, energy, and commodities markets.

III. The Interbank Clearing System operated by GIRO Zrt (BKR) is charged with the management of credit institutions' mass low amount payments (transfers and collections).

In addition, you should mention the Post Office Clearing House (PEK) for the settlement of postal payments, the clearing/settlement systems operated by international card federations for bank card transactions and CLS international foreign exchange trading system operated by the National Bank of Hungary (MNB) (Kovács et al., 2016; MNB, 2020).

\subsection{The Interbank Clearing System (BKR)}

Most transfers and collections are linked to domestic business activity. Although international payments have continuously increased over the past years, crossborder transactions rarely exceed $2-3 \%$ of payments in small and open economies like our country.

In Hungary clearing and settlement of domestic interbank transactions is executed by the Interbank Clearing System (BKR) operated by GIRO Zrt. Clearing/ settlement is fully electronic with no human intervention via protected communication channels, which contributes to stability and maintains confidence in the banking system (Kovács, 2017).

BKR operates in three settlement modes:

- InterGIRO1 (IG1), a night settlement mode in operation since 1994, supports the clearing/settlement of all payment modes of transfer or collection in line with the provisions of the MNB regulation on the execution of payment transactions. (Dávid-Kovács 2019)

- InterGIRO2 ( $\mathrm{IG}_{2}$ ) launched on 2 July 2012 is responsible for the daytime settlement of payments only. At the start it operated in 5 (or 3 on Saturdays) cycles, but it has been running 10 (7 on Saturdays) cycles since 7 September 2015.

- GIROInstant Platform was launched on 2 March 2020, which provides clearing/settlement of HUF based domestic electronic payments mostly below HUF 10 million within a few seconds in every hour and on every day of the year (penzforgalom.hu). 


\subsection{The Instant Payments System}

Instant Payments is a transfer-type mode of payments. It means, in essence, the uninterrupted clearing/settlement of HUF based domestic electronic transfers mostly below HUF 10 million within a few seconds.

As a supplementary service, Instant Payments allows transfers to be launched without knowing the relevant account numbers using so termed secondary account identifiers (mobile telephone number, e-mail address or tax ID). Payment request is another convenience service, which is a message. It allows the beneficiary to initiate a transfer order. The transfer order takes effect on approval by the paying party. Here is an example for demonstration: a seller sends a message to its buyer's phone with a payment request equal the total amount of the purchase; by accepting the request the buyer sends its account managing bank an automatically generated transfer order, so the financial settlement of the sale-purchase is executed.

Instant payment is in fact „cash without cash” since it is a convenient and a competitive alternative to cash payment (GIRO Zrt, penzforgalom.hu).

It is outstanding even in global terms that Instant Payments were introduced simultaneously by all payment service providers in the Hungarian banking industry thanks to the fruitful collaboration of GIRO Zrt and the National Bank of Hungary, while in other countries using similar systems the service typically covers certain parts of the banking system only (MNB, 2020; Kovács, 2016).

\section{THE COVID-19 PANDEMIC AND ITS EFFECTS IN HUNGARY}

Chinese health authorities officially reported to the World Health Organisation (WHO) of a pneumonia epidemic caused by the SARS-CoV-2 virus in late December 2019. The new so termed coronavirus had been identified in the city of Wuhan, capital of Hubei province (WHO website). In the months to follow, the disease quickly spread in China then in the whole world.

In the European Union, the first infection was reported in France on 24 January 2020. In its publication in February 2020, the European Centre for Disease Prevention and Control (ECDC) officially termed the disease „coronavirus disease 2019", COVID-19 in short (ECDC website).

The WHO declared the epidemic to be a pandemic on 11 March 2020. In the middle of March, in line with the new number of cases, the WHO deemed Europe rather than China was the active hotbed (Váradi et al., 2020). In the following 
period the further spread of the infection to the American and African continents was unstoppable.

In Hungary, the first infection related to the SARS-CoV-2 virus was reported on 4 March and the first death on 15 March.

The pandemic did not only exert unforeseen pressure to the health systems of different countries, but it was a shock to the economy at large. That is proved by negative GDP figures for Q1 and Q2 2020 from all regions of the world. Blocking followed by the lockdown of international transport of people and goods, the resulting "freeze" of global trade and tourism and the breakdown of production chains generated a global economic crisis. Different countries, international organisations (WBG, IMF) as well as the EU and OECD strived to stop or mitigate the drastic economic recession. The management of the labour market (mass unemployment), and support provided for household consumption and corporate lending (liquidity) were of primary importance (Baldwin et al., 2020).

The government of Hungary made efforts according to their means to intervene from the beginning of the pandemic and provided economic stimulus in the emergency period (from 11 March to 18 June).

A new so termed economy protection action plan was announced and launched on 7 April, which also included intervention to reduce administrative, payment and tax burden (kormany.hu). Its main components were the following:

- Payment moratorium, i.e. deferment of retail and corporate loans,

- taking over wages by the government (up to $70 \%$ for 3 months) for the period work stopped,

- accelerated tax refund and deferred tax returns (for businesses),

- free online training courses, termination of language exam obligation, student loans with favourable interest rates,

- suspension of tourism tax (IFA).

As a result of the pandemic, lending declined significantly, which could only be mitigated by government programmes (Baby Shower Loan) and initiatives by the National Bank of Hungary (Go, NHP). In terms of corporate lending, the launch of "Go, NHP” as well as the discount loan schemes by the Hungarian Bank of Development and Eximbank drove lending activity while in terms of households launching the Family Housing Allowance (CSOK) programme and lending related to the Baby Shower Loan could support lending (MNB, 2O2ob).

In the following part we have based our findings and conclusions on information gained from the Interbank Clearing System (BKR). However, on studying lending, in addition to clearing/settlement figures (e.g. evolution of collections under the title loan repayment), you should also rely on the data of the Central 
Credit Information System (KHR). KHR figures reflect that, as a result of new programmes and easing constraints, queries on credit information were close to base level in June following extremely low figures in April and May (10.0\% and $17.1 \%$ decline), which indicated a revival of lending (KHR - GIRO/BISZ). ${ }^{2}$

\section{FOUR MONTHS' CLEARING/SETTLEMENT IN FIGURES}

\subsection{Methodology}

Studying payments figures is an effective method of analysing several segments of the economy. The volume and values of electronic transactions are a good representation of the underlying business events, so the data on certain types of transactions might be good economic indicators.

Statistical indicators should be used comparing them to the same period of the base year to eliminate seasonality. That is what we did on several occasions for BKR, however, we studied the evolution of volume by itself (monthly sum) or compared to the previous month in the case of instant payments (GIROInstant platform). Its reason was partly that we had no figures on the same period of the previous year and, on the other hand, if a new service is launched, it is interesting to see how volumes expand from month to month.

\subsection{The Interbank Clearing System (BKR)}

Considering that the BKR covers most payments by both natural persons and legal entities, the evolution of its volumes provides immediate feedback on the performance of the economy. The crisis of the coronavirus resulted in a slowdown or shutdown in several industries reflected in the number of tax payments, wages, or loan repayments. Analysing the volume of BKR in March, April, May, and June, you could observe the impact of government measures to alleviate the epidemic and protect the economy.

Studying the whole of the Interbank Clearing System (BKR), at the beginning of the period you could observe a fast increase of volume (6.3\%) in March 2020, followed by two poor „coronavirus” months $(-2.1 \%$ and $-6.4 \%)$, while in June the volume of BKR showed the second highest growth of the year (+4.1\%).

2 Base: the same month last year (June 2019) 
Table 1

Payments of Interbank Clearing System, monthly figures

\begin{tabular}{|c|c|c|c|c|c|c|c|c|}
\hline \multirow{2}{*}{$\begin{array}{l}\text { Payment } \\
\text { categories }\end{array}$} & \multicolumn{4}{|c|}{$\begin{array}{l}\text { Number of payments }-2020 \\
\text { (thousand) }\end{array}$} & \multicolumn{4}{|c|}{$\begin{array}{l}\text { Changes from the same month } \\
\text { in } 2019(\%)\end{array}$} \\
\hline & March & April & May & June & March & April & May & June \\
\hline Single Payment & 19506 & 18014 & 17427 & 18061 & $10,3 \%$ & $2,0 \%$ & $-3,8 \%$ & $8,2 \%$ \\
\hline Direct debit & 6677 & 6065 & 6114 & 6186 & $1,8 \%$ & $-9,7 \%$ & $-9,6 \%$ & $-2,3 \%$ \\
\hline Multiple payment & 6713 & 6842 & 6351 & 6699 & $1,7 \%$ & $-2,4 \%$ & $-7,8 \%$ & $2,1 \%$ \\
\hline $\begin{array}{l}\text { PSC (Postal } \\
\text { Settlement Centre) }\end{array}$ & 560 & 570 & 519 & 587 & $-1,0 \%$ & $-8,7 \%$ & $-10,1 \%$ & $-0,1 \%$ \\
\hline Rejection/refusal & 355 & 231 & 235 & 247 & $-8,1 \%$ & $-41,5 \%$ & $-42,4 \%$ & $-31,5 \%$ \\
\hline Total (ICS) & 33811 & 31723 & 30644 & 31780 & $6,3 \%$ & $-2,1 \%$ & $-6,4 \%$ & $4,1 \%$ \\
\hline
\end{tabular}

Source: GIRO Zrt.

\subsubsection{Single payments}

The volume of single payments - particularly the strikingly high increase of business-related payments - characterised the sum of interbank clearing in March. The two surplus working days or economic growth can be decisive factors of the increase. The March volume was a real surprise as it reflected nothing of the economic difficulties caused by the coronavirus. Since important sectors of the economy (e.g. motor industry, tourism, catering or construction) had to face extremely difficult market conditions from one minute to the next, its impact had to be felt on the volume of business related payments sooner or later. With respect to tax type payments, a volume reducing effect of the moratorium on tax payment could be similarly predicted.

Volumes in April declined by $\mathbf{2 . 1 \%}$ in total compared to the same period of the previous year, which has been unprecedented since the 2008 crisis, so it was a definite warning. In the same month, the volume of individual transfers was still rising (+2.0\%), but you could observe a drastic reduction $(-9.1 \%)$ of typically tax type payments to the Treasury. That can be explained by the easing of tax and contribution payment obligations for businesses in the endangered sectors. The $4.7 \%$ growth of business type payments remained a promising sign, but their growth rate declined within the month. Forecasts by both the government and researchers suggested adverse economic indicators for Q2 while the performance of $\mathrm{H}_{2}$ depended on how much the economy could be restarted in an optimal bal- 
ance with protection from the epidemic. All that had, naturally, a direct impact on interbank settlements.

As it could be expected, the number of transactions declined significantly - by $6.4 \%$ - in May. Almost every branch of the economy had to endure double pressure. Production slowed down due to a reduction of demand from outside and the drop of employment and breakdown of supply chains from the inside. Industrial output declined by $36.8 \%$, exports by $7.3 \%$ and imports by $5.5 \%$.

The composition of volumes differed from that of April since the freeze of the economy to such an extent resulted in a decline in the volume of individual transactions. The volume fell back significantly in the month; not only tax type but also business-related transactions declined (by $-12.7 \%$ and $-1.5 \%$ respectively), the latter to a lower rate.

Analysts' estimations at the end of May suggested the economy had already bottomed out, which was seemingly also supported by developments of the virus situation both in this country and internationally. Nobody expected, however, that the number of transactions would grow so fast in June. The two surplus working days compared to the base month might have accounted for a 3-5\% volume increase. Adjusted, the base-level June volume was still the second highest economic performance of Q2. This sharp rise was driven by single $(+8.2 \%)$ including business related single payment transactions (+11.5\%). It was a promising feature for the whole of economic development, although the value of payments cleared was still declining in terms of single payments $(-3.2 \%)$ indicating a further decline of the economy, which corresponds to different forecasts by analysts. In any case, you could draw the conclusion from payment figures that the performance of the Hungarian economy may have started to increase as restrictions were lifted in May.

Within single payments the volume of tax type items continued to decline (-7.3\%) as a result of the moratorium on tax payment, but considering its ratio, it could only dampen the strong growth of business type items.

\subsubsection{Multiple payments}

Volumes of Direct Debit (DD) slightly increased in March by $1.7 \%$ following a decline in January and February. Then there followed a significant decline in April and May ( $-9.7 \%$ and $-9.6 \%$, respectively). It was not, however, caused by the deterioration of the business environment. What happened was that the moratorium of loan payments - a part of DD - resulted in a sharp decline of funding type items $(-27.5 \%$ and $-25.3 \%$, respectively) as public utilities and insurance were stagnating or slightly growing. 
In June the volume of utility items - within DD - increased similarly to business type single payments (11.0\%), the volume of funding items continued to decline drastically $(-20.9 \%)$ - due to the moratorium - while insurance was stagnant (+0.4\%).

As for two major components of DD, SZÉP cards were the driving force of growth in March. The increase in the volume of SZÉP cards was closely related to a government decision cancelling social contribution tax on SZÉP cards first till 30 June and - pursuant to a government decree on 22 May - till the end of 2020 (Government Decrees No 140/2020 and 225/2020).

An increase in direct group transfers was driven by a $2.2 \%$ increase of pensions which made up for more than a third of the volume. In the case of another component, indirect group transfers, they were stagnant in March since wages making up $60.0 \%$ of the volume were also stagnant. Considering the seasonal high level of the employment base, a $0.6 \%$ growth could be deemed favourable but the growth, in fact, was the result of delayed financial settlement of wages. Incomes are typically paid following the given month, so payment figures can only provide feedback on a quickly changing employment situation a month later. Therefore, the bad news of employment in March were not clearly reflected in the volume of March transfers. However, labour data at the time suggested a decline and only its size was a question.

In April multiple payments declined to a lesser extent (-2.4\%). Indirect multiple payments are important business indicators, so their significant decline in April $(-8.5 \%)$ was a clear sign of the sudden shock to the Hungarian economy. There was a slowdown in every area: wages -5.5 , benefits $-18.4 \%$, SZÉP cards $-9.2 \%$. Wages within direct multiple payments $(+1.2 \%)$ also declined considerably $(-6.1 \%)$, while pensions resistant to the crisis $(+2.1 \%)$ and decisive because of their ratio held that transaction type at base level.

The decline in the volume of multiple payments in May was unambiguously caused by the drop of employment levels. Wages and wage related benefits declined most $(-11.2 \%$ and $-18.1 \%$, respectively), the volume of pensions could increase alone $(+2.1 \%)$.

In June, the volume of multiple payments was outstanding $(+2.1 \%)$ including $+7.7 \%$ for direct multiple payments, explained by the sudden increase in the volume of SZÉP cards $(+135.7 \%)$ and others not specified (+43.1\%). The figures of business type indirect multiple payments $(-6.7 \%)$ do not support a possible surge of economic growth but clearly reflect the further decline of employment. The fall of volumes is caused by wages $(-8.1 \%)$, wage related benefits $(-21.5 \%$ ( and SZÉP cards $(-9.1 \%)$. The latter figure suggests that the abolition of social contribution tax on SZÉP cards in the private sector could only slightly support a boost of do- 
mestic tourism. The values settled declined slightly less as opposed to the number of wage transfers (wages $-3.7 \%$, wage related benefits $-9.1 \%$ ), which suggests the increase of average wages. To sum up, the volume of multiple payments was under a strong adverse business pressure (indirect multiple payments) and an equally strong beneficial non-business influence (direct multiple payments) in June, which jointly resulted in a volume growth not to be underestimated.

\subsubsection{Postal settlements (PEK)}

Contrary to the $8-10 \%$ decline in PEK volumes in earlier months, it was stagnant in June $(-0.1 \%)$ as a combined result of the increase of unemployment benefit $(+69.4 \%)$ and employment substituting support (+53.5\%) set off by the decline of benefits $(-44.5 \%)$ and other titles $(-9.5 \%)$. The volume of PEK items is a clear reflection of the situation on the labour market because of the crisis, as the number and ratio of different employee support items within the transaction type significantly increased in the period analysed.

\subsection{Instant payments}

Instant payments were launched in Hungary on 2 March at oo:oo hours successfully with no glitches. The central clearing/settlement mechanism operated by GIRO Zrt has been normally operating since its launch. Following a long and resourceful test period, both the central infrastructure and the banking applications passed the test with flying colours, all contributors to the system took the leap successfully.

\subsubsection{How long is „instant”?}

In theory, the payment transactions meeting the criteria of acceptance in the instant payment system are executed in 5 seconds. Figures from the first 4 months suggest it is the case in practice (Figure 1). 
Figure 1

Processing time of instant payments (March-June 2020)

\section{Total payment processing}

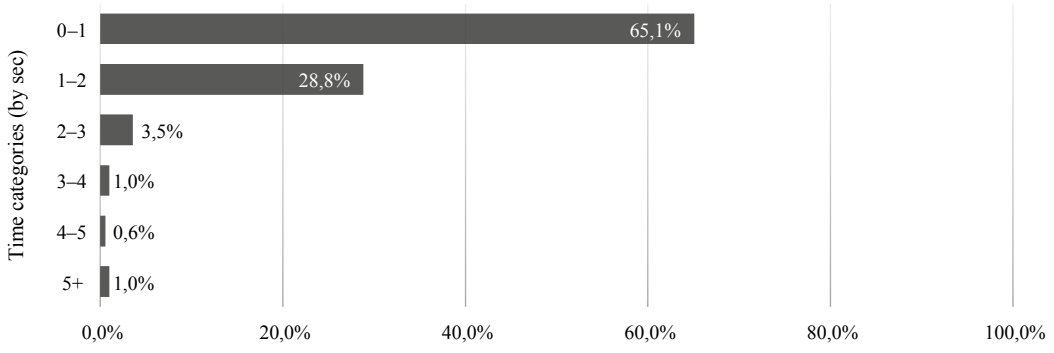

Distribution of settled payments (\%)

Payment processing time by GIRO

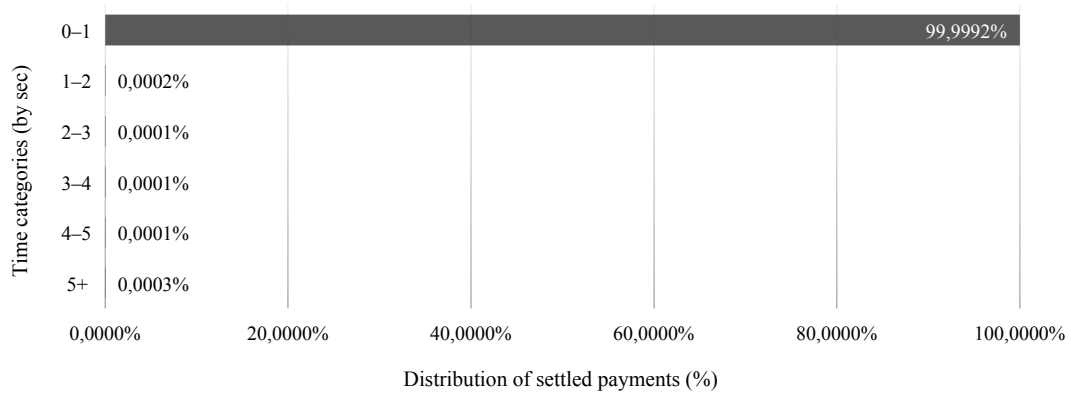

Source: own design using GIRO Zrt data

The performance of the central infrastructure of instant payments has met expectations; almost all transactions were processed by the clearing house in less than 1.6 seconds $^{3}$ (99.9992\%). The total time calculated for the whole of the clearing/settlement system is also favourable, $99 \%$ of payments were credited on the accounts of receiving banks within 5 seconds and $93.9 \%$ within 2 seconds. Thus, the IT systems supporting instant payments carried out their duties as expected even in peak times.

3 Deadline for the processing of 95 percent of instant payment transactions received on GIROInstant platform as per standard accepted by GIRO Zrt pursuant to the Rules of Operation of the Interbank Clearing System. 


\subsubsection{Features of instant payments during the start-up period}

35.8 million transactions worth HUF 5.115 billion had been cleared/settled in Instant Payment System from its live start until the end of June. Table 2 is a summary of the monthly figures.

Table 2

Payments of Instant Payment System, monthly figures

\begin{tabular}{lrrrr}
\hline & March 2020 & \multicolumn{1}{c}{ April 2020 } & \multicolumn{1}{c}{ May 2020 } & \multicolumn{1}{c}{ June 2020 } \\
\hline Volume (pieces) & 9323871 & 9018830 & 8882098 & 8584442 \\
Value (HUF) & 1363672405222 & 1248190394991 & 1226780242238 & 1276562297843 \\
\hline
\end{tabular}

Source: penzforgalom.hu; GIRO Zrt.

Instant payment is the safest way of payment in a pandemic. At the start of the system experts believed that realising this and implementing the system in practice may mitigate the reduction of transactional volumes resulting from the expected slowdown of the economy.

As expected, protection measures against the coronavirus had their impact on the operation of the instant payment system. Transaction numbers gradually declined for 4 months, while transaction values started to increase in June following two months of reduction.

The biggest decline of the Interbank Clearing System (-6.4\%) occurred from April to May although the number of instant payments was only reduced by a mere $1.5 \%$ at that time. At the same time the reduction of single payment transactions cleared on the InterGIRO2 platform was $5.2 \%$, which can probably be explained by the reduction of batch corporate transfer numbers resulting from the slowdown of the economy due to the coronavirus.

The ratio of the new GIROInstant platform in total volumes was slightly above $50 \%$ at the start. In June GIROInstant volumes declined while InterGIRO2 volumes significantly increased (8.7\%), causing a slight fall of the ratio of the new platform (to $47.8 \%$ ). The clearing/settlement of batch corporate transfers in the instant payment system from 1 September is expected to result in a leap in their ratio. Another push to instant payments may result from mandatory electronic payment by online cash registers from the beginning of 2021.

According to instant payment regulations, payments up to HUF 10 million must be cleared through the new platform, but members of the clearing house also processed higher amount single items in the instant payment infrastructure in the period analysed. However, it did not have a material impact on total volumes or values; although there occurred transactions worth several hundred million 
HUF, they only numbered a few items. Low amount transactions were dominant in the system; at the start (in March) the ratio of transactions of individual values below HUF 10 thousand was $37 \%$ while $97 \%$ of the total volume consisted of transactions below HUF 1 million.

Instant payments in the field of supplementary services are gaining ground at a moderate rate for the time being. Secondary account identification or payment requests are still sporadic; in June $0.04 \%$ of instant payments were launched linked to an e-mail address, tax ID or taxpayer identification number (TIN) while transactions settled on payment requests failed to reach $0.01 \%$. It can also be the result of the mandatory use of the new platform for payments while there is no such obligation regarding supplementary services. Thus, a much slower ramp up of the latter can be envisaged.

Figure 2 illustrates the daily distribution of instant payments. It presents the average volume and value figures of 168 hours so that bank holidays ( 15 March, 1 May, Easter and Pentecost) have been omitted. Thus, the visual data represent an average week and its days of the Instant Payment System.

The distribution of payments within a day is much like InterGIRO2; volumes peak during working hours. You can see minimum number of transactions (a few hundred per hour) during the night and at dawn, then there is an sharp increase - steeper than linear - from 5 to 8 hours a.m. peaking from 10 to 11 hours a.m. on average (almost 40 thousand payments per hour). Lower values from 12 a.m. to 1 p.m. clearly indicate lunchtime. After that, the curve is slightly falling back for the afternoon hours with 28 to 33 thousand payments per hour. There is a sharp fall after 4 p.m. while volumes gradually diminish to almost nil after 9 p.m.

As for the weekly distribution of payments, it is not surprising that volumes are much lower at weekends. The number of payments at weekends is $27.8 \%$ and values are $\mathbf{1 2 . 1 \%}$ compared to working days.

The first days of the week (Monday to Thursday) are quite similar. Wednesdays and Thursdays are almost identical while volumes are slightly higher on Mondays and Tuesdays. Transaction numbers start diminishing sooner and steeper on Friday afternoons due to shorter working hours and the approaching weekend.

On Saturdays you can see a rather low but stable number of transactions with a peak from 10 a.m. to 11 a.m. similarly to weekdays. Sunday is the most interesting day from the perspective of data analysis since instant payments have been launched. Volumes are surprisingly high (34\% higher than on Saturdays) and unlike on other days - there is a peak (from a fairly high figure from 10 a.m. to 12 a.m.) from 7 p.m. to 9 p.m. with approximately 10 thousand payments per hour, which suggests a kind of pre-start of work for the following week. 


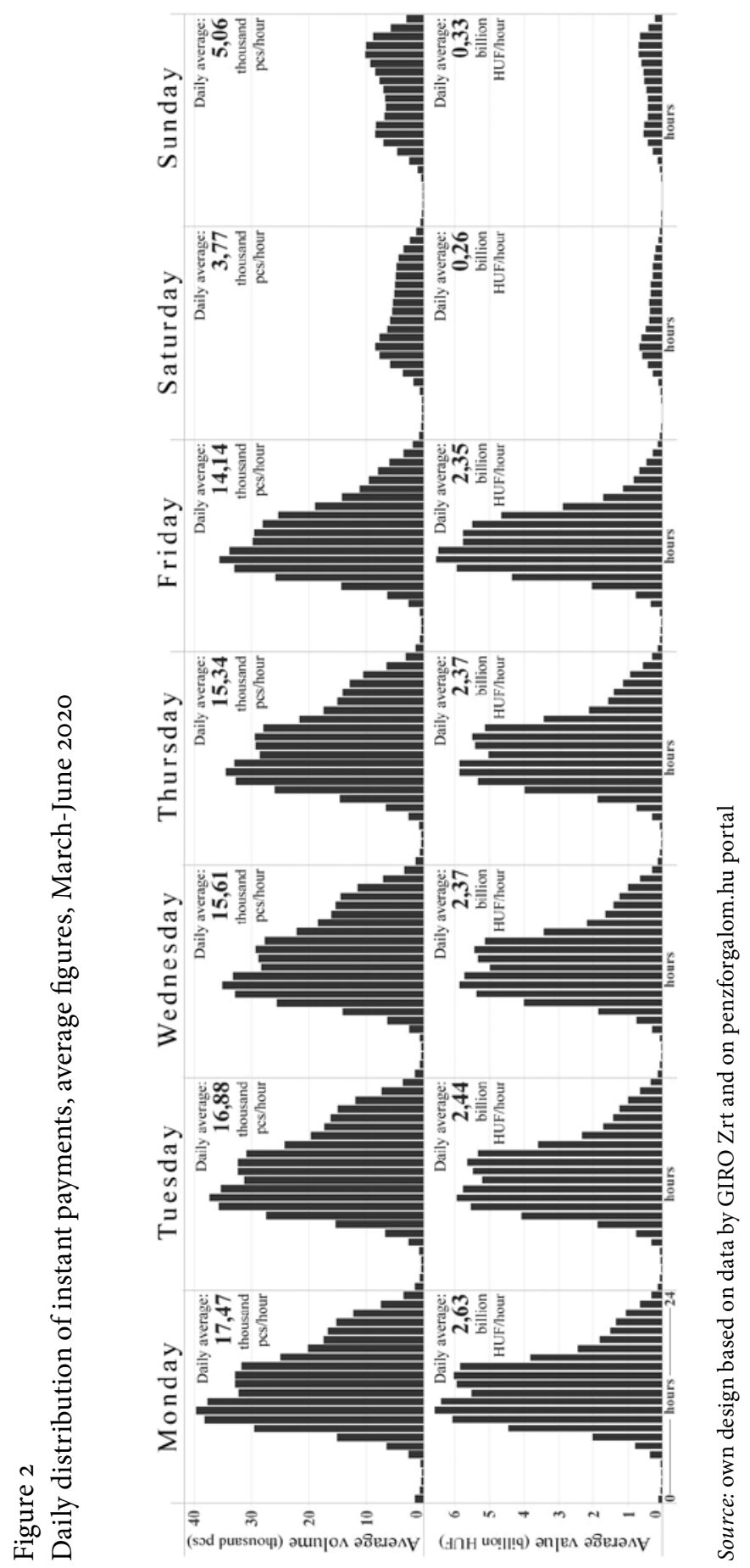




\section{SUMMARY}

The launch of the Instant Payment System coincided with the implementation of restrictive measures to fight the coronavirus. The pandemic and the related circumstances have hindered the spread and monitoring of the instant payment system, on the other hand, it is an excellent opportunity to analyse the impact of this special situation using the data of the clearing system.

You cannot neglect the general economic environment on examining the roll-out of an innovation in payments. In our case revealing the connections between the figures of the clearing system and business events or regulations is particularly important.

The coronavirus did not have a material impact on the March volume of the Interbank Clearing System (BKR), later, however, there was a significant downturn as the economy slowed down in general. It was reflected both in the number of single and multiple transfers because of massive job losses, and in the numbers of Direct Debit due to the loan repayment moratorium and the shrinking insurance market. In June, some positive trends could be observed.

The virus situation did have an impact on the volumes of the Instant Payment System, but the infrastructure passed the test with flying colours. The system was launched smoothly and has been operating normally ever since. Future volumes will depend on how the pandemic develops and how historic government measures to protect the economy can alleviate its effects. A real breakthrough for instant payments can start after the period of preventive measures restricting the economy comes to an end.

It is, nevertheless, clear we should continue to analyse the correlation of the performance of the Hungarian economy and the operation of the clearing system. 


\section{REFERENCES}

Baldwin, R. - Weder di Mauro, B. (2020): Economics in the Time of COVID-19. CEPR Press Centre for Economic Policy Research, London, p. 115, ISBN: 978-1-912179-28-2.

DÁvid, SÁndor - Kovács, LEVEnte (2019): the development of clearing services - paradigm shift. Economy and Finances 6(3), 296-310.

GIRO Zrt. (2020): Rule of Operation of the Interbank Clearing System [Bankközi Klíring Rendszer Üzletszabályzata], GIRO Zrt., effective as of 2 March 2020, BoD Resolution No 1/2020/1 (https:// www.giro.hu/szolgaltatasok/bankkozi-kliring-rendszer\#).

Kovács, Levente - Divéki, Éva - DÁvid, SÁndor - PÁl, Zsolt - Kada, Zsolt (2016): A kis értékü pénzforgalom és elszámolási rendszerei [Low value payments and settlement systems]. Miskolc: Miskolci Egyetemi Kiadó.

Kovács Levente (2017): Pénzügyi szektor a bizalmatlanság markában [The financial sector in the grip of distrust]. In: Kovács Levente - Sipos JózSef (2017): Ciklusváltó évek, párhuzamos életrajzok [Cycle-changing years, parallel biographies], 9-26, http://bankszovetseg.hu/ Public/publikacio/Ciklusv\%C3\%A1t\%C3\%B3\%20\%C3\%A9vek\%2C\%2op\%C3\%A1rhuzamos\%2O $\% \mathrm{C}_{3} \%$ A9letrajzok.pdf.

National Bank of Hungary (2020a): Fizetés Rendszer Jelentés [Payment System Report], Budapest, July 2020, ISSN 2498-7077.

National Bank of Hungary (2020b): Pénzügyi Stabilitási Jelentés [Financial Stability Report], Budapest, May 2020. ISSN 2064-941X.

VÁradi, A. - Ferenci, T. - FAlus, A. (2020): A koronavírus okozta COVID-19-pandémia pandémia [The COVID-19 pandemic caused by the coronavirus]. Orvosi Hetilap 161(17), 644-651.

\section{Government regulations}

140/2020. (IV. 21.) Korm. rendelet - A Gazdaságvédelmi Akcióterv keretében a koronavírus-járvány gazdasági hatásainak mérséklése érdekében szükséges adózási könnyítésekről [Government Decree No 140/2020 (IV.21.) on tax incentives required to mitigate the economic effects of the coronavirus epidemic in the framework of the Economic Protection Plan].

225/2020. (V. 22.) Korm. rendelet - A Gazdaságvédelmi Akcióterv keretében a koronavírus-járvány gazdasági hatásainak mérséklése érdekében szükséges adózási könnyítésekről szóló 140/2020. (IV. 21.) Korm. rendelet módosításáról [Government Decree No 225/2020. (V. 22.) on tax incentives required to mitigate the economic effects of the coronavirus epidemic in the framework of the Economic Protection Plan on the amendment of Government Decree No 140/2020 (IV.21.)].

\section{Websites}

Information page on the coronavirus, Government of Hungary: https://koronavirus.gov.hu/.

WHO website: https://www.euro.who.int/en/health-topics/health-emergencies/coronavirus-covid-19. ECDC website: https://www.ecdc.europa.eu/en/coronavirus.

Gazdaságvédelmi Akcióterv [Economic Protection Plan - website of the Government of Hungary]: https://www.kormany.hu/hu/hirek/a-gazdasagvedelmi-akcioterv-fobb-pontjai.

\section{Data sources}

A Bankközi Klíring Rendszer adatai [Data of the Interbank Clearing System], GIRO Zrt., www. penzforgalom.hu.

A Központi Hitelinformációs Rendszer adatai [Data of the Central Credit Information System], GIRO Zrt.; BISZ Zrt.

National Bank of Hungary: Elszámolásforgalmi rendszerek nyitvatartási naptára, 2019-2020 [Clearing system - opening calendar 2019-2020], https://bit.ly/33X33Ip. 